(C) 2016, Elsevier. Licensed under the Creative Commons Attribution-NonCommercial-NoDerivatives 4.0 International http://creativecommons.org/licenses/by-nc-nd/4.0/

\title{
INTERNAL COMMUNICATION AND PROSOCIAL SERVICE BEHAVIORS OF FRONT-LINE EMPLOYEES: INVESTIGATING MEDIATING MECHANISMS
}

\author{
Neeru Malhotra and Anna Ackfeldt
}

\section{Introduction}

It is well established within the services marketing and management literature that front-line employee (FLE) prosocial service behaviors (PSBs) strongly influence customers perceptions of service quality and satisfaction (e.g. Bettencourt \& Brown, 1997; Bettencourt et al., 2005), which, in turn, affect organizational effectiveness and performance (Podsakoff et al. 2009). PSBs are defined as "helpful behaviors of employees directed towards the organization or other individuals" (Bettencourt \& Brown, 1997, p. 41). As PSBs are discretionary behaviors that go beyond formal role requirements, and are found to be positively associated with both organizational and customer relationship performance (Bettencourt \& Brown, 1997), these are highly valued by service firms. Given the significance of PSBs, (Podsakoff et al., 2009), more research is called for to understand what motivates these, and how management can help to promote PSBs among FLEs (Bettencourt \& Brown, 2003; Podsakoff et al., 2009; Winterich et al., 2013). Considering that different types of FLE behaviors have been shown to have different antecedents (MacKenzie et al., 1998; Podsakoff \& MacKenzie, 1997), more research into different dimensions of PSBs is also warranted (Bettencourt \& Brown, 2003; Podsakoff \& MacKenzie, 1997). However, relatively few studies have addressed this gap in literature (excluding for instance Ackfeldt \& Wong, 2006; Bettencourt et al., 2005; Bettencourt \& Brown, 1997, 2003; Lages, 2012).

In view of the above, literature suggests that research investigating antecedents of prosocial behaviors mainly falls into two broad categories: one that is focused on studying individual-difference variables (such as dispositions or job attitudes), and the other that 
studies contextual variables (Winterich et al., 2013). However, research in both these categories has been 'almost entirely' focused on motivational variables (Dudley \& Cortina, 2008), neglecting other important variables like knowledge and communication. This is because motivation has been regarded as the "overriding proximal predictor of citizenship performance" in literature (Dudley \& Cortina, 2008, p.1249). Thus, more research investigating predictors, especially situational predictors (Rank et al., 2007), that could facilitate the effective performance of such behaviors has been repeatedly called for (Dudley \& Cortina, 2008; Lee et al., 2006; Rank et al., 2007). In this context, although a few studies have looked at the impact of management interventions like empowerment (Ackfeldt \& Wong, 2006), training, rewards (Lee et al. 2006), fairness perceptions (Bettencourt \& Brown, 1997), task variables (Piccolo \& Colquitt, 2006) and leadership (De Cremer et al., 2009; Rank et al., 2007), research investigating the influence of internal communication on FLE PSBs remains extremely limited (Ackfeldt \& Wong, 2006).

Literature suggests four levels of internal communication: internal line management communication, internal team peer communication, internal project peer communication and internal corporate communication (see Welch \& Jackson 2007). While most empirical work in services literature has focused mainly on internal line management communication in the form of either supervisor communication practices or feedback (Johlke \& Duhan, 2000, 2001; Johlke et al., 2000; Yoo et al. 2014), it is important to study internal organizational communication (also known as internal corporate communication (Welch \& Jackson, 2007) or management communication (Ng et al., 2006)), as literature highlights "the need for organizations to recognize employees as a distinct public worthy of individualized attention" (Mishra et al. 2014, p.185). Because internal communication between the organization and its employees helps to engage employees" "intellectual and creative assets to produce value" (Quirke, 2008, p. 15), instils a sense of ownership in employees (Soupata, 2005), enhances 
employees' psychological attachment towards the organization and encourages them to contribute to organizational goals (Rousseau, 1998), it is being increasingly recognized as "a vital issue requiring further research" (Hargie \& Tourish, 2009, p. 419). Although internal marketing literature conceptually talks about the benefits of internal organizational communication for FLE performance (George, 1990; Rafiq \& Ahmed, 2000), empirical research verifying and testing its significance remains negligible ( $\mathrm{Ng}$ et al., 2006; Tkalac Verčič et al. 2012), especially for frontline PSBs as "extant services research focuses far more on managing customer relationships than on the dynamics of effectively supporting and developing the service personnel who interact with customers" (Ellinger et al. 2013, p.1124). As such, empirical research examining the significance and role of internal communication is warranted to help organizations understand how internal communication could foster an effective internal service climate that encourages and supports prosocial behaviors among FLEs, which are crucial for any service organization's success. Addressing such gaps in literature, we focus on organization's internal communication (hereinafter referred to as 'internal communication') in this study, which is defined as 'the extent to which organizations provide organization-related information to their employees, such as information about changes in organizational policies and procedures, financial results, employee and group successes, and customer feedback" (Ng et al., 2006, pp. 476-77).

As empirical findings establishing the significance of internal communication for FLE performance are not only limited but also mixed (see Ackfeldt \& Wong, 2006; Carrière \& Borque, 2009; $\mathrm{Ng}$ et al., 2006), research is required to gain a deeper understanding of the mechanisms by which internal communication may influence employee PSBs. Since PSBs are not so simple that anyone can do them effectively (Dudley \& Cortina, 2008), it would be useful to identify those variables and/or mechanisms that facilitate these behaviors in organizational settings (Podsakoff et al., 2009). In this context, relatively little empirical 
research has centered attention on understanding other alternative mechanisms besides employee attitudes (e.g. Ackfeldt \& Wong, 2006; Lages, 2012; Lee et al., 2006). For instance, because role stress is inevitable in boundary-spanning roles (Singh, 2000), and can directly influence FLE behaviors and their attitudes (Bettencourt \& Brown, 2003), Bettencourt et al. (2005) suggest that future PSB research frameworks might benefit by incorporating FLE role stress to better understand the mechanisms by which PSBs could be developed. In particular, previous studies overlook PSB antecedents (such as internal communication and role stress), and the interrelationships among these key variables in a comprehensive framework to understand how internal communication could facilitate the development of PSBs among FLEs.

Drawing on attitude (Bagozzi, 1992) and role (Solomon et al., 1985; Walker et al., 1975) theories, we address the above notable gaps and multiple calls in the service management literature by developing and testing a research framework to understand how internal communication may influence PSBs. Particularly, we investigate the nature of relationships among internal communication, role stress and organizational commitment on two types of PSBs: extra-role customer service and cooperative behaviors. In this study, we specifically focus on these two types of PSBs, because both extra-role customer service behaviors and cooperation are discretionary behaviors with a strong flavor of service orientation that "clearly involve helping others with or preventing the occurrence of workrelated problems" (Podsakoff et al., 1997, p. 263), which are especially critical for the success of service organizations (Bettencourt \& Brown, 1997; MacKenzie et al., 1998). Our main argument is that internal communication plays a crucial role in positively influencing FLEs organizational commitment whilst simultaneously diminishing the negative effects of role stress, thereby enhancing FLE extra-role customer service and cooperative behaviors. 
The remainder of our paper is organized as follows. We present the conceptual framework and develop the hypotheses in the next section. The methodology is then explained, followed by the findings of our study. Finally, the research findings are discussed along with the implications of the findings for theory and practice, the major limitations of the study, and recommendation for future research.

\section{Conceptual framework and research hypotheses}

PSBs may be directed at either customers or co-workers (Bettencourt \& Brown 1997). Extrarole customer service behaviors refer to discretionary behaviors of FLEs in serving customers that extend beyond their formal role requirements (Bettencourt \& Brown, 1997). Cooperation refers to helpful behaviors of FLEs that are internally directed towards the organization, and towards other members of their immediate workgroup (Bettencourt \& Brown, 1997). Previous literature suggests that employee behaviors could be explained using both attitude and role theories. We develop our conceptual framework by integrating both these theories, which we describe below.

\subsection{Attitude theory}

Bagozzi (1992) argues that self-regulatory processes guide behavior. Specifically, individuals assess situational conditions, which lead to emotions, and subsequently induce coping responses (behavior); thus, the sequence of appraisal processes or cognitive evaluations of events, emotional responses and behavior. For example, when one experiences a pleasant event, one feels a sense of satisfaction and joy, which leads one to attain the outcome (Bagozzi, 1992). In contrast, when one experiences an unpleasant event, situation or outcomes, it leads to negative reactions such as dissatisfaction or distress, which in turn results in behaviors that are guided to reduce or eliminate the outcome. Based on attitude 
theory, our conceptual framework assumes that perceptions of internal communication (appraisal), leads to organizational commitment (emotional response), which then leads to employees engaging in PSBs directed towards colleagues (cooperation) and customers (extrarole service behavior).

\subsection{Role theory}

Role theory has been utilized to explain attitudes and behaviors by marketing researchers (Coelho et al., 2011). According to this theory, individual's perceptions of their role are determined by their perceived influences from role senders (such as supervisors and customers), and their own perceptions of how their role should be performed (Walker et al., 1975). Based on role theory, role ambiguity and role conflict have been identified as two key aspects of role stress. Role stress mainly results due to need for flexibility during interactions with customers and others in the role set (Singh, 1993), and may also be influenced by managerial actions, including "the extent to which managers clearly define priorities for employees, communicate activities to be performed, and articulate evaluation mechanisms" (Coelho et al., 2011, p. 33).

Following role theory, effective internal communication between management and employees should reduce the role stress that employees perceive in their boundary-spanning positions, which also should enhance their organizational commitment and PSBs. However, attitude theory suggests that employee appraisals of the contextual factors (i.e. perceptions of internal communication practices) should influence their PSBs through the mediating mechanism of organizational commitment. Thus, drawing on attitude and role theories, our study proposes a conceptual framework (see Fig.1), whereby both organizational commitment and role stress are expected to mediate the relationships between internal 
communication and extra-role customer service/cooperative behaviors. Attention now turns to the development of the research hypotheses that underpins the conceptual framework.

"Insert Fig. 1 about here"

\subsection{Research Hypotheses}

Organizational commitment may be regarded as the relative strength of individual employees' involvement with, loyalty to and identification with organizations (Allen \& Meyer, 1990). Findings from many empirical studies have shown that organizational commitment is associated with numerous important outcomes, including reducing turnover and absenteeism, as well as increasing job performance, productivity levels and OCBs (e.g. Ellinger et al., 2013; Lages, 2012; MacKenzie et al., 1998). It is, therefore, expected that committed employees are more likely to engage in extra-role service and cooperative behaviors (Ackfeldt \& Wong, 2006; Bettencourt \& Brown, 1997). We, consequently, propose that:

H1: Organizational commitment positively influences a) extra-role customer service and b) cooperative behaviors.

Role ambiguity and role conflict. It is well established that in their role as boundaryspanners, FLEs are susceptible to experiencing some level of role stress (e.g. Ackfeldt \& Malhotra, 2013; Örtqvist \& Wincent, 2006). Role stress mainly comprises role ambiguity and role conflict (Singh, 1998; Örtqvist \& Wincent, 2006). Role ambiguity refers to FLEs' perceptions of lack of clear and salient information, which they need to perform the job role adequately. Role conflict, on the other hand, occurs when a FLE perceives that the demands and expectations of two or more members of their role set (i.e. managers, supervisors, 
colleagues and customers) are incompatible or incongruent (Agarwal \& Ramaswami, 1993; Singh, 1998;). While role ambiguity enhances uncertainties associated with performing the role, conflicting expectations from different role partners makes it difficult for FLEs to decide how best to accomplish any task (Hartline \& Ferrell, 1996); both role ambiguity and role conflict are detrimental for service organizations (Mukherjee \& Malhotra, 2006; Singh, 2000).

Previous research demonstrates that role ambiguity and conflict are expected to be negatively correlated with FLE discretionary behaviors (Bettencourt \& Brown, 2003; MacKenzie et al., 1998). Researchers argue that FLEs experiencing high levels of role stress may perceive their organization as being unsupportive and unfair (Addae \& Parboteeah, 2008). Such employees are likely to "have a poor picture of how their tasks relate to other jobs, to people inside and outside the organization, and to the firm's overall goals" (Coelho et al., 2011, p. 34). Therefore, role stressors are generally linked to behavioral withdrawals (Bettencourt \& Brown, 2003). Jex (1998) suggests that the negative effects of role stress on employee behaviors may be most evident in reduced contributions of extra-role behaviors or PSBs, because reducing PSBs does not threaten either their receipt of formal organizational rewards or their membership with the organization (Bettencourt \& Brown, 2003). In fact, reduced performance of employee discretionary behaviors is regarded as an early sign of behavioral withdrawal (MacKenzie et al., 1998). FLEs who do not clearly understand the expectations of their multiple role partners along with their role requirements in terms of responsibilities, appraisal, rewards, and their degree of freedom during interactions with internal (colleagues) and external customers, are less likely to engage in discretionary behaviors. Thus, we hypothesize that: 
H2: Role ambiguity is negatively related to a) extra-role customer service behaviors and b) cooperation.

H3: Role conflict is negatively related to a) extra-role customer service behaviors and b) cooperation.

Consistent with role theory, findings from past research shows a negative relationship between role stress and organizational commitment (e.g. Ackfeldt \& Malhotra, 2013; Örtqvist \& Wincent, 2006). The relationships between role ambiguity/role conflict and organizational commitment are based on the premise that individual FLEs work in an environment that is characterized by high role stress are less willing to get involved and emotionally attached with their organization (Örtqvist \& Wincent, 2006). In accordance with role episode model (Kahn et al., 1964), persistent role stressors are likely to overwhelm FLE's resources, and have a dysfunctional impact on FLEs' behavioral and psychological job outcomes, such as organizational commitment. FLEs experiencing high role stress tend to view the organization in adversarial terms, and are inclined to withdraw psychologically from it as they do not believe that their job provides them with a sense of accomplishment (Singh et al., 1994). Accordingly, we hypothesize:

H4: a) Role ambiguity and b) role conflict are negatively related to organizational commitment.

Internal Communication is an important aspect of organizational communication, and is often perceived as a synonym for intra-organizational communication. Internal communication entails "all forms of communication within the organization" (Tkalac Verčič et al., 2012, p. 225) that need to be conveyed in a way these are clearly understood by 
employees responsible for their implementation ( $\mathrm{Ng}$ et al., 2006). Literature suggests that internal communication varies from informal chat and office gossip to formal corporate communication to all employees from senior management (Welch, 2012). Here, we focus on formal corporate communication, because it reflects on management endeavors that enable FLEs to provide superior customer service (Mishra et al., 2014). The importance of effective internal communication cannot be overstated. Internal communication aids in developing positive internal relationships by enabling communication between senior management and employees. Successful internal communication is vital, because it can "promote employee awareness of opportunities and threats, and develop employee understanding of their organization's changing priorities" (Welch, 2012, p. 246). The key benefits of internal communication include improved productivity, reduced absenteeism, higher quality of services and products, increased levels of innovation, and reduced costs (Clampitt \& Downs, 1993; Tkalac Verčič et al., 2012).

As service providers to both internal and external customers, FLEs require information on customer needs, about their organization, and on how their contribution is vital to the organization and its customers in order to be able to perform their jobs well (Conduit \& Mavondo, 2001; Ruck \& Welch, 2012). Internal communication provides employees with the essential knowledge and skills about both their jobs and the organization, and enables them to become 'organizational advocates' (Grönstedt, 2000). Without effective internal communication, FLEs would lack the necessary knowledge and information, and would not feel confident in their jobs.

As discussed above, one of the objectives of internal communication is to improve the flow of all information to employees, which is likely to enhance role clarity. As role ambiguity is a function of lack of information and decision-making by employees (Johlke \& Duhan, 2000), management are able to reduce the role ambiguity that employees may 
experience by communicating pertinent and timely information relating to the organization, their jobs and customers' needs and wants (Nelson et al., 2007). Thus, FLEs who clearly understand their roles in terms of why and how their tasks fit into the organization's objectives and efforts should experience less role ambiguity (Johlke \& Duhan, 2000).

Findings from empirical studies relating to the nature of the relationship between internal communication and role conflict are minimal. However, it is logical to assume that sufficient and timely knowledge and information provided to FLEs about the job, organization and its customers will enable them to better understand the expectations of their multiple role partners (e.g. customer and colleagues). Consequently, FLEs are likely to be more adept in deciding how best to perform their tasks in order to effectively satisfy their role partners. Thus, effective and timely internal communication is expected to abate the challenges posed by the inevitable role conflict experienced by FLEs in their boundary spanning positions (Ackfeldt \& Malhotra, 2013). Hence, we hypothesize that:

H5: Internal communication is negatively related to a) role ambiguity and b) role conflict

Amongst other various positive outcomes suggested by literature, internal communication has been found to influence organizational commitment positively (Carrière \& Bourque, 2009; Ng et al., 2006). This is because internal communication increases employees' psychological attachment to their organization, as “it encourages employees to perceive themselves as core members of the organization and to contribute to the organization's goals" (Ng et al., 2006, p. 477). When employees do not get timely, accurate and relevant information from management, they are likely to feel more vulnerable and less trustworthy of management (Thomas et al., 2009). In fact, literature establishes organizational commitment as "a by-product of the processes and policies that are designed 
to make the relationship satisfactory for both parties, such as open, appropriate, clear and timely communication" (Chia 2005, p. 7). Hence, we hypothesize:

H6: Internal communication is positively related to organizational commitment.

\section{Method}

\subsection{Context and sample}

Data was collected in a UK travel service organization, which offers short cruises for travel and tourism purposes. The respondents work in a range of customer-contact roles, including sales, customer service desks, waiters, bar staff and cashiers. Although the services offered are routine and fairly standardized, the organizations customers are diverse (business and tourist passengers) with different needs and expectations of service. The organization communicates regularly with its employees using various forms of internal communication (i.e. weekly newsletters, internal memos and departmental meetings to inform the employees about departmental plans, job requirements, and up-dates in HR polices). Before the data collection started, management pre-announced the study in internal memos. Participation in the study was also encouraged by further endorsing the study in the weekly newsletter and departmental meetings. Thus, the organization's internal communications channels were fully utilized to encourage participation in the study.

A survey packet was distributed to 520 FLEs through the organization's internal mail system. The survey packet contained a cover letter from the researcher, a self-completion survey, and a free-post envelope addressed to the researcher. The cover letter explained the academic study, and that it was supported by management. It also provided information about how to complete the questionnaire, that there were no right or wrong answer to the statements, and assurances were made that respondents would remain anonymous as the 
survey was mailed directly to the researcher. The cover letter was, consequently, designed to control for common method bias (Podsakoff et al., 2003). The conceptual framework of the study was not revealed to further reduce such bias. To improve the response rate, a reminder was placed in the internal newsletter the week after initial distribution. Three weeks after the first survey packet was distributed, a second one was mailed out.

188 questionnaires were returned, but four questionnaires were excluded due to high levels of missing data. We were left with 184 usable questionnaires, i.e. an effective response rate of $34.6 \%$ that is in line with previous research on FLEs (c.f. Lages, 2012). In terms of demographic characteristics of respondents, $65 \%$ are men. $57 \%$ are in the 18 to 35 age bracket. $91 \%$ are tenured, and $38 \%$ have 10 years or more experience with the organization. The majority of respondents are team members, $68.6 \%$, with a roughly equal proportion of male and female FLEs, and $93.4 \%$ of supervisory/managerial positions are held by men.

We tested for non-response bias by comparing early and late respondents on measured demographic characteristics (Armstrong \& Overton, 1977). There were no significant differences in the gender, age, education, tenure or organizational position of early and late respondents. The findings of the non-response bias tests suggest this issue is not significant.

\subsection{Measures}

In order to be consistent with the literature, multi-item measures used in the survey were the drawn and adapted from existing scales that have been used in services contexts. Extra-role customer service and cooperation behavior were measured using the scales from Bettencourt and Brown (1997) and Ackfeldt and Wong (2006). Organizational commitment was measured using the affective commitment scale by Allen and Meyer (1990). Role ambiguity and role conflict scales were adapted from Rizzo, House and Lirtzman (1970) and Agarwal and Ramaswami (1993). Finally, internal communication was measured using a 
modified and shortened version of Clampitt and Downs' (1993) communication scale, as used by Conduit and Mavondo (2001). This scale comprises three dimensions:

Organizational perspective, which refers to the broadest kind of information about the organization as a whole that the employees receive. It includes items on notification about important changes in the organization, information about its financial position, and overall policies and goals. Organizational integration refers to the degree to which employees receive information about the immediate work environment, such as information about departmental plans, the requirements of their jobs, and other personnel news. Media quality deals with the extent to which meetings are well organized, written directions and guidelines are clear and concise, and the degree to which the amount of written communication (i.e. newsletters, brochures, magazines, and internal memos) is adequate. All constructs are measured on 7-point Likert-type scales, anchored by "1 = strongly disagree" and "7 = strongly agree".

\section{Data analysis}

\subsection{Measurement and structural models}

Latent variable structural equation modeling (SEM) using AMOS 20.0 (Arbuckle, 2011) was adopted as the method of analysis for this study. SEM is considered to be an appropriate technique for empirical model building (Bollen \& Long, 1993) because it permits the simultaneous estimation of multiple and interrelated dependence relationships (Fornell \& Larcker, 1981) whilst accounting for measurement error in the estimation process (Hair et al., 1998). To assess the measurement properties, the items were first subjected to a confirmatory factor analysis (CFA). The fit statistics for the CFA model are as follows: $\mathrm{CFI}=.92$, TLI=.91, $\mathrm{IFI}=.92, \mathrm{RMSEA}=.05$. Our results indicate that internal communication emerged as a unidimensional construct with all three dimensions loading on a single factor. Because all factor 
loadings are strongly significant and the composite reliability for the scales exceed .70 (range from .72 to .91), internal consistency and convergent validity of the scales is supported. There is also evidence of discriminant validity (Fornell and Larcker, 1981). Refer to Table 1 for the correlations, means, standard deviation, composite reliability, AVE and Cronbach's Alpha for the scales used in this study.

Harman's single-factor test was also performed, and we also ran single-factor confirmatory analysis (using AMOS 20.0) with all items loading on a single common method variance factor to assess whether common method variance (CMV) is a concern. $23.3 \%$ of the variance was explained by Harman's single-factor. The fit indices of the resulting singlefactor $\mathrm{CFA}(\mathrm{CFI}=.50, \mathrm{TLI}=.47, \mathrm{IFI}=.51, \mathrm{RMSEA}=.13)$ indicates that the six constructs in the conceptual framework are different, and CMV is not a major concern. We also employed the marker variable technique (Lindell \& Whitney, 2001). A marker variable is one that is theoretically unrelated with one or more research variables of interest in the study. As such, CMV can be indicated based on the correlation between the marker variable and the research variables (Malhotra et al., 2006). We included 'social desirability' as marker variable in our study, which is measured by 5 items (Hays et al., 1989). The correlations matrix indicates that the marker variable is found to be unrelated to all $(-.02$ to $-.13 ; \mathrm{p}>.05)$ but one research variable where the correlation was found to be low (.19). We also included the marker variable in our measurement model and compared the two models, with and without the marker variable. The results remained stable as none of the significant correlations became insignificant, indicating that $\mathrm{CMV}$ is not a major concern in our study. Attention now turns to the testing the hypotheses, i.e. the estimation of the structural model.

"Insert Table 1 about here"

The model fit statistics of the structural model are as follows: $\mathrm{CMIN}=611.48, \mathrm{DF}=$ $395, p<.000, \mathrm{CFI}=.91, \mathrm{TLI}=.90, \mathrm{IFI}=.91, \mathrm{RMSEA}=.06$. The standardized parameter 
estimates for the structural model and significance levels are reported in Table 2. In support of hypotheses $1 \mathrm{a}$ and $1 \mathrm{~b}$, the relationships between organizational commitment and extra-role customer service $(.32, \rho \leq .01)$ and cooperative $(.27, \rho \leq .01)$ behaviors are positive and significant. As predicted in hypotheses $2 \mathrm{a}$ and $2 \mathrm{~b}$, role ambiguity has strong negative relationships with extra-role customer service $(-.48, \rho \leq .01)$ and cooperative $(-.65, \rho \leq .01)$ behaviors. Hypotheses $3 \mathrm{a}$ and $3 \mathrm{~b}$ are rejected, because the proposed negative relationships between role conflict and extra-role customer service and cooperative behaviors are not supported. However, both parameter estimates are positive and significant $(.22, \rho<.01 ; .15, \rho$ $<.10$ ), although the relationship between role conflict and cooperative behaviors is somewhat weak at $\rho<.10$. Hypotheses $4 \mathrm{a}$ and $4 \mathrm{~b}$ are rejected, because the proposed effects of role ambiguity/conflict on organizational commitment are non-significant (.15 respectively $-06 ; \rho$ $>$.01). Internal communication does not significantly influence either extra-role customer service or cooperation behaviors $(-.05, \rho>.10 ;-.05 ; \rho>.10)$. Thus, hypotheses $5 \mathrm{a}$ and $5 \mathrm{~b}$ are not supported. Consistent with hypotheses 6 , the relationship between internal communication and organizational commitment is strongly positive $(.49, \rho<.01)$. Thus, the results of the structural model broadly support our conceptual framework.

\section{"Insert Table 2 about here"}

We also tested for mediation effects using bootstrapping analysis in AMOS, which is preferred to Sobel tests as the latter has its limitations because it assumes the sampling distribution of the indirect effect to be normal (e.g. Hayes, 2009; Preacher \& Hayes, 2004; 2008; Zhao et al., 2010).We tested the significance of indirect effects as recent literature indicates that the only requirement qualifying mediation is the significance of indirect effects (Zhao et al., 2010). The results (see Table 3) demonstrate that all indirect effects except one are significant thereby establishing mediation. In all these cases, we also found evidence of full mediation (Baron \& Kenny, 1986). 
"Insert Table 3 about here"

\section{Discussions, Limitations, Future Research and Conclusions}

Our study significantly contributes to service management literature by investigating the impact of organization's internal communication on the two types of PSBs, incorporating the mediating mechanisms of role stress and organizational commitment in a single parsimonious framework. While previous empirical studies have found direct effects of supervisor communication practices on employees' job performance (see Johlke and Duhan, 2000; Johlke et al. 2000), our findings indicate that organization-related information provided by organization's internal communication system influences their prosocial behaviors indirectly. Moreover, in contrast with previous findings that did not find role ambiguity to mediate the effects of supervisor communication practices on employee job outcomes (Johlke and Duhan, 2000), our findings demonstrate role stress and commitment to fully mediate the link between organizational internal communication and PSBs. As such, our findings provide useful insights on the mediating mechanisms by which organization's internal communication influences PSBs. Reinforcing the contention in literature that the link between management practices and employee performance may be better explained by mediating variables (Batt, 2002; Ellinger et al., 2013), our results highlight the significance of studying role stress and organizational commitment as mediators in the relationship between internal communication and PSBs. This useful finding implies that different levels of internal communication practices can impact employee outcomes differently. While line management communication or the communication between employees and their immediate line manager influences employee outcomes directly, the impact of organization's internal communication on PSBs seems to be rather indirect. 
Previous empirical research on the relationship between internal communication and organizational commitment has been limited and equivocal (see Ackfeldt \& Wong, 2006; Ng et al., 2006), but our results fully support this link. Internal communication practices demonstrate and reinforce organizational support and care towards its employees, and help FLEs identify with their organization and its goals, thereby eliciting a sense of belonging towards their organization.

Consistent with previous research on supervisor communication practices (Johlke et al., 2000; Nelson et al., 2007), the proposed links between organization's internal communication and role ambiguity/conflict are found to be negative. Our findings demonstrate that availability of pertinent information from the organization enables FLEs to better understand how to perform their jobs well (Nelson et al., 2007). Because internal communication enhances FLEs knowledge of their jobs and the organization, it helps FLEs in coping with the inherent challenges of their boundary-spanning positions by reducing uncertainties about their roles and responsibilities, and thereby diminishing their role stress.

Consistent with attitude theory, organizational commitment is found to exert a strong, positive influence on both extra-role customer service and cooperative behaviors. Thus, FLEs who are psychologically attached to the organization and identify with its goals tend to go beyond their call of duty to help out their customers and colleagues. Similarly, in line with role theory, the negative relationships between role ambiguity and extra-role customer service and cooperative behaviors are strongly supported. This indicates that FLEs who are unclear about their roles and responsibilities are dissuaded from engaging in any form of discretionary behavior.

However, the relationships between role conflict and extra-role customer service and cooperative behaviors are positive in this study. Although previous findings with respect to the effects of role conflict on employee behavior and performance have been mixed (see 
Coelho et al., 2011), our findings lend support for a positive relationship rather than a negative one. In this context, our findings demonstrate that the positive effects of role conflict are more significant for extra-role customer service $(\rho<.01)$ as compared to cooperative behavior $(\rho<.10)$. Thus, the challenges induced by role conflict seem to be particularly useful for FLEs when dealing with customers rather than colleagues. Possibly, as role conflict is inevitable in front-line jobs, FLEs cope with it by being more creative in approaching task challenges (Coelho et al., 2011) and look out for constructive solutions (Goolsby, 1992) that can address perceived incompatibility among the expectations of their role partners (like customers and fellow colleagues). In this context, our findings indicate that one such solution seems to be engaging in extra-role behaviors/PSBs (Bettencourt \& Brown, 2003). Because customers represent the central focus of FLEs' efforts and are the key source of firm's revenue (Johlke et al. 2000), when faced with role conflict, FLEs work hard and travel the extra mile to especially satisfy the demands and expectations of their customers, as role conflict significantly enhances their extra-role customer service behaviors.

In contrast with most previous findings (Singh, 1998; Örtqvist \& Wincent, 2006), our findings indicate that role stress does not have a significant relationship with organizational commitment, thereby, indicating that role stress has a direct impact on PSBs rather than an indirect one. Possibly, as role stress increases, employee behaviors become inefficient, misdirected, or insufficient (Michaels et al., 1987). Thus, role stress seems to exert an immediate direct negative impact on PSBs. The crucial role played by internal communication in positively enhancing organizational commitment on the one hand, and diminishing the effects of role stress on the other, may also be responsible for this insignificant relationship. However, future research should test this relationship further.

From a managerial perspective, our findings indicate that customer-contact service organizations wishing to engage their FLEs in PSBs must pay attention to improving the 
quality of internal communication with their FLEs. Effective communication of organizationrelated information significantly influences employees' psychological attachment towards their organization and enhances their commitment, which, in turn, spurs their discretionary behaviors towards both fellow colleagues and customers. Besides enhancing organizational commitment, it also diminishes FLE role stress regarding their roles and responsibilities. Although role ambiguity is detrimental and influences PSBs negatively, our findings indicate that some role conflict is beneficial as it seems to boost PSBs. Hence, managers should craft the internal communication practices with circumspection as too much information might actually take away the challenges induced by role conflict that is required to stimulate FLE discretionary customer service behaviors and good citizenship.

There are some limitations of our study that should be considered. This study is based on self-reported, cross-sectional data. Consistent with literature that advocates CMV problem to be less of a concern in mono-method studies (Spector, 2006), our CMV tests demonstrate that it is not a problem in this study. However, future studies should aim for longitudinal designs. It may also be prudent to include supervisory evaluations of FLE PSBs to validate our findings. Also, data collected from cross-cultural contexts (Podsakoff et al., 2009) across a range of service organizations in multiple service industries may enhance the generalizability of our findings (Lages, 2012).

Future research might also incorporate alternate mechanisms and boundary conditions to shed more light on the processes by which internal communication influences employee job attitudes and behaviors. It might help to study different dimensions/levels of internal communication in tandem to demonstrate any potential trade-offs between internal and external PSBs. Although internal communication is found to influence FLE role stress negatively, our findings also indicate that some role conflict is actually desirable for stimulating PSBs. Hence, it would be useful to further probe into the internal communication- 
role stress-PSB relationships. Finally, in future, the model could be extended to incorporate other important consequences like employee turnover, service quality and customer satisfaction to gain an in-depth understanding of the significance of internal communication and PSBs for both internal as well as external customers.

In conclusion, our study highlights the importance of organization's internal communication, and is likely to stimulate future research attention on further understanding the significance and role of internal communication in services. The study's key theoretical contribution to the services literature lies in the integration of attitude and role theories to explain the mediating mechanisms by which internal communication influences PSBs. As such, the study findings may be beneficial for both academics and practitioners in understanding the nature and role of internal communication for improving FLE prosocial service behaviors. 


\section{References}

Ackfeldt, A.-L. \& Malhotra, N. (2013), "Revisiting the Role Stress-Commitment Relationship: Can Managerial Interventions help?," European Journal of Marketing, 47(3/4), $353-374$.

Ackfeldt, A.-L. \& Wong, V. (2006), “The Antecedents of Prosocial Service Behaviours: An Empirical Investigation,” The Service Industries Journal, 26(7), 727-745.

Addae Helena M. \& K. Praveen Parboteeah (2008), "Role stressors and organizational commitment: public sector employment in St Lucia", International Journal of Manpower, 29(6), 567-582.

Agarwal, S. \& Ramaswami, S.N. (1993), "Affective Organizational Commitment of Salespeople: An Expanded Model," Journal of Personal Selling \& Sales Management, XIII (2), 49-70.

Allen, N.J. \& Meyer, J.P. (1990), "The Measurement and Antecedents of Affective, Continuance and Normative Commitment in the Organization," Journal of Occupational Psychology, 63, 1-18.

Arbuckle, J. L. (2011). Amos (Version 20.0) [Computer Program]. Chicago: SPSS.

Armstrong, J. S. \& Overton, T.S. (1977), "Estimating Nonresponse Bias in Mail Surveys," Journal of Marketing Research, XIV (August 1977), 396-402.

Bagozzi, R. P. (1992), “The Self-Regulation of Attitudes, Intentions, and Behavior,” Social Psychology Quarterly, 55(2), 178-204.

Baron, R.M. \& Kenny, D.A. (1986), “The moderator-mediator variable distinction in social psychological research: Conceptual, strategic, and statistical considerations," Journal of Personality and Social Psychology, 51(6), 1173-1182.

Batt, R. (2002), “Managing customer services: Human resource practices, quit rates, and sales growth," Academy of Management Journal, 45(3), 587-597. 
Bettencourt, L.A. \& Brown, S.W. (1997), “Contact Employees: Relationships Among Workplace Fairness, Job Satisfaction and Prosocial Service Behaviors," Journal of Retailing, 73(1), 39-61.

Bettencourt, L.A. \& Brown, S.W. (2003), "Role Stressors and Customer-Oriented BoundarySpanning Behaviors in Service Organizations," Journal of the Academy of Marketing Science, 31(4), 394-408.

Bettencourt, L.A., Brown, S.W. \& MacKenzie, S.B. (2005), “Customer-Oriented BoundarySpanning Behaviors: Test of a Social Exchange Model of Antecedents, Journal of Retailing, 81(2), 141-157.

Bollen, K. \& Long, J.S. (1993), Testing Structural Equation Models, Sage, London.

Carrière, J. \& Bourque, C. (2009), "The Effects of Organizational Communication on Job Satisfaction and Organizational Commitment in a Land Ambulance Service and the Mediating Role of Communication Satisfaction," Career Development International, 14(1), 29-49.

Chia, J. (2005), “Measuring the immeasurable?" Retrieved from http://www.prismjournal.org/fileadmin/Praxis/Files/Journal_Files/Evaluation_Issue/C HIA_ARTICLE.pdf

Clampitt, P.G. \& Downs, C.W. (1993), "Employee Perceptions of the Relationship between Communication and Productivity", Journal of Business Communication, 30 (1), 5-28. Coeleho, F., Augost, M. \& Lages, L.F. (2011), “Contextual Factors and the Creativity of Frontline Employees: The Mediating Effects of Role Stress and Intrinsic Motivation," Journal of Retailing, 87(1), 31-45.

Conduit, J. \& Mavondo, F.T. (2001), “How Critical Is Internal Customer Orientation to Market Orientation,” Journal of Business Research, 51, 11-24. 
De Cremer, D., Mayer, D.M., van Dijke, M., Schouten, B.C. \& Bardes, M. (2009), "When Does Self-Sacrificial Leadership Motivate Prosocial Behavior? It Depends in Followers' Prevention Focus,” Journal of Applied Psychology, 94(4), 887-899.

Dudley, N.M. \& Cortina, J.M. (2008), “Knowledge and Skills That Facilitate the Personal Support Dimension of Citizenship,” Journal of Applied Psychology, 93, 1249-1270. Ellinger, A.E., Findley Musgrove, C., Ellinger, A.D., Bachrach, D.G., Elmadağ Baş, A.B., \& Yu-Lin Wang, Y.-L. (2013), "Influences of organizational investments in social capital on service employee commitment and performance," Journal of Business Research, 66(8), 1124-1133.

Fornell, C. \& Larcker, D.F. (1981), "Evaluating Structural Equation Models with Unobservable Variables and Measurement Error," Journal of Marketing Research, XVIII(February), 39-50.

Goolsby, J.R. (1992), “A Theory of Role Stress in Boundary Spanning Positions of Marketing Organisations", Journal of the Academy of Marketing Science, 20, 155-64.

Hair, J.F., Anderson, R.E. Jr., Tatham, R.L., \& Black, W.C. (1998), Multivariate Data Analysis (5 ${ }^{\text {th }}$ ed.), Upper Saddle River: Prentice-Hall Inc.

Hays, R.D., Hayashi, T. \& Stewart, A.L. (1989), “A five-item measure of socially desirable response set," Educational and Psychological Measurement, 49, 629-636.

George, W. R. (1990), “Internal marketing and organizational behavior: a partnership in developing customer-conscious employees at every level," Journal of Business Research, 20(1), 63-70.

Grönstedt, A. (2000). The customer century: Lessons from world-class companies in integrated marketing communication, New York, NY: Routledge.

Hargie, O., \& Tourish, D. (2009), Auditing organizational communication, London: Routledge. 
Hartline, M.D. \& Ferrell, O.C. (1996), “The Management of Customer-Contact Employees: An Empirical Investigation," Journal of Marketing, 60(4), 52-70.

Jex, S.M. (1998), Stress and Job Performance: Theory, Research, and Implications for Managerial Practice, Thousand Oaks, CA: Sage.

Johlke, M.C. \& Duhan, D.F. (2000), “Supervisor Communication Practices and Service Employee Job Outcomes,” Journal of Service Research, 3(2), 154-165.

Johlke, M.C. \& Duhan, D.F. (2001), "Supervisory Communication Practices and Boundary Spanner Role Ambiguity,” Journal of Managerial Issues, XIII(I), 87-101.

Johlke, M.C., Duhan, D.F., Howell, R.D. \& Wilkes, R.W. (2000), “An Integrated Model of Sales Managers' Communication Practices," Journal of the Academy of Marketing Science, 28(2), 263-277.

Kahn, R.L., Wolf, D.M., Quinn, R.P. \& Snoek, J.D. (1964), Organizational Stress: Studies in Role Conflict and Ambiguity. New York: Wiley.

Lages, C.R. (2012), “Employees’ External Representation of their Workplace: Key Antecedents", Journal of Business Research, 65, 1264-1272.

Lee. Y.-K., Nam, J.-H., Park, D.-H., \& Lee, K.A. (2006), "What factors influence customeroriented prosocial behaviour of customer-contact employees?, “ Journal of Services Marketing, 20(4), 251-264.

Lindell, M. K., \& Whitney, D. J. (2001). Accounting for common method variance in crosssectional designs. Journal of Applied Psychology, 86, 114-121.

MacKenzie, S.B., Podsakoff, P.M. \& Ahearne, M. (1998), “Some Possible Antecedents and Consequences of In-Role and Extra-Role Salesperson Performance," Journal of Marketing, 62(July), 87-98. 
Malhotra, N., Kim, S.S. \& Patil, A. (2006), “Common Method Variance in IS Research: A Comparison of Alternative Approaches and Reanalysis of Past Research,'” Management Science, 52(12), 1865-1883.

Hayes, A.F. (2009), “Beyond Baron and Kenny: Statistical Mediation Analysis in the New Millennium,' Communication Monographs, 76(4), 408-420.

Michaels, R.E., Day, R.L. \& Joachimsthaler, E.A. (1987), “Role Stress Among Industrial Buyers: An Integrative Model," Journal of Marketing, 51(2), 28-45.

Mishra, K., Boynton, L., \& Mishra, A. (2014), “Driving Employee Engagement: The Expanded Role of Internal Communication," International Journal of Business Communication, 51(2), 183-202.

Mukherjee, A. \& Malhotra, N. (2006), "Does Role Clarity Explain Employee-Perceived Service Quality? A Study of Antecedents and Consequences in Call Centres," International Journal of Services Industry Management, 17(5), 444-473.

Nelson, S., Brunetto, Y., Farr-Wharton, R. \& Ramsay, S. (2007), “Organizational Effectiveness of Australian Fast Growing Small to Medium-sized Enterprises (SMEs)," Management Decision, 45(7), 1143-1162.

Ng, T.W.H., Butts, M.M., Vandenberg, R.J., DeJoy, D.M. \& Wilson, M.G. (2006), "Effects of Management Communication, Opportunity for Learning, and Work Schedule Flexibility on Organizational Commitment," Journal of Vocational Behavior, 68(2006), 474-489.

Piccolo, R. F. \& Colquitt, J. A. (2006), “Transformational leadership and job behaviors: The mediating role of core job characteristics," Academy of Management Journal, 49, $327-340$. 
Podsakoff, P.M. \& MacKenzie, S.B. (1997), "Impact of Organisational Citizenship Behavior on Organisational Performance: A Review and Suggestions for Future Research," Human Performance, 10(2), 133-151.

Podsakoff, P.M., MacKenzie, S.B, Podsakoff, N.P. \& Lee, J.-Y. (2003), “Common Method Biases in Behavioral Research: A Critical Review of the Literature and Recommended Remedies, Journal of Applied Psychology, 88(5), 879-903.

Podsakoff, N.P., Whiting, S.W., Podsakoff, P.M. \& Blume, B.D. (2009), "Individual- and Organizational-Level Consequences of Organizational Citizenship Behaviors: A Meta-Analysis," Journal of Applied Psychology, 9(1), 122-144.

Preacher, K.J. \& Hayes, A.F. (2004), “'SPSS and SAS Procedures for Estimating Indirect Effects in Sample Mediation Models,', Behavioral Research Method, Instrument and Computer, 36(4), 717-731.

Quirke, B. (2008), Making the connections: Using internal communication to turn strategy into action, Burlington, VT: Gower.

Rafiq, M. \& Ahmed, P. K. (2000), “Advances in the internal marketing concept: definition, synthesis and extension," Journal of Services Marketing, 14(6), 449-462.

Rank, J., Carsten, J.M., Unger, J.M. \& Spector, P.E. (2007), "Proactive Customer Service Performance: Relationship With Individual Task, and Leadership Variables,” Human Performance, 20(4), 363-390.

Rizzo, J.R., House, R.J. \& Lirtzman, S. (1970), "Role Conflict and Ambiguity in Complex Organizations," Administrative Science Quarterly, 15(2), 150-163.

Rousseau, D. M. (1998), "Why workers still identify with organizations,” Journal of Organizational Behavior, 19, 217-233.

Ruck, K. \& Welch, M. (2012), "Valuing internal communication: management and employee perspectives," Public Relations Review, 38, 294-302. 
Singh, J. (1993), "Boundary Role Ambiguity: Facets, Determinants, and Impacts," Journal of Marketing, 57(2), 11-31.

Singh, J. (1998), "Striking a Balance in Boundary-Spanning Positions: An Investigation of Some Unconventional Influences of Role Stressors and Job Characteristics on Job Outcomes of Salespeople," Journal of Marketing, 62(July), 69-86.

Singh, J. (2000), "Performance Productivity and Quality of Frontline Employees in Service Organizations," Journal of Marketing, 64(2), 15-34.

Singh, J., Goolsby, J.R. \& Rhoads, G.K. (1994), “Behavioral and Psychological Consequences of Boundary Spanning Burnout for Customer Service Representatives", Journal of Marketing Research, 31, 558-569.

Solomon, M.R., Suprenant, C. Czepiel, J.A. \& Gutman, E.G. (1985), "A Role Theory Perspective on Dyadic Interactions: The Service Encounter," Journal of Marketing, 49(Winter 1985), 99-111.

Soupata, L. (2005), "Engaging employees in company success: The UPS approach to a winning team," Human Resource Management, 44, 95-98.

Spector, P. E. (2006). Method Variance in Organizational Research: Truth or Urban Legend? Organizational Research Methods, 9, 221-232.

Thomas, G. F., Zolin, R., \& Hartman, J. L. (2009),'The central role of communication in developing trust and its effect on employee involvement," Journal of Business Communication, 46, 287-310.

Tkalac Verčič, A., Verčič, D. \& Sriramesh, K. (2012), “Internal communication: Definition, parameters, and the future," Public Relations Review, 38, 223-230.

Walker Jr., O.C., Churchill Jr., G.A. \& Ford, N.M. (1975), “Organizational Determinants of Industrial Salesman's Role Conflict and Ambiguity," Journal of Marketing, 39(1), 3239. 
Welch, M. (2012), “Appropriateness and acceptability: Employee perspectives of internal communication," Public Relations Review, 38, 246-254.

Welch, M. \& Jackson, P.R. (2007), "Rethinking internal communication: A stakeholder approach," Corporate Communications: An International Journal, 12(2), 177-198.

Wintericht, K.P., Aquino, K., Mittal. V., \& Swartz, R. (2013), “When Moral Identity Symbolization Motivates Prosocial Behavior: The Role of Recognition and Moral Identity Internalization,” Journal of Applied Psychology, 98(5), 759-770.

Yoo, J., Flaherty, K. \& Frankwick, G.L. (2014), “The effect of communication practice on deviance among Korean salespeople: The mediating role of intrinsic motivation," Journal of Business Research, 67, 1991-1999.

Zhao, Xinshu, John G. Lynch, Jr., \& Qimei C. (2010), “'Reconsidering Baron and Kenny: Myths and Truths about Mediation Analysis,' Journal of Consumer Research, 37(2), 197-206.

Örtqvist, D. \& Wincent, J. (2006), "Prominent Consequences of Role Stress: A MetaAnalytical Review," International Journal of Stress Management, 13(4), 399-422. 
Table 1

Means, Standard Deviation, Composite Reliability, Average Variance Extract,

Cronbach's $\alpha$, Squared Correlations and Inter-Correlations

\begin{tabular}{|l|r|r|r|r|r|r|r|r|r|r|}
\hline & Means & SD & CR & AVE & 1. & 2. & 3. & 4. & 5. & 6. \\
\hline 1.ERCS & 5.69 & .87 & .85 & .59 &. $\mathbf{8 7}$ & .35 & .08 & .18 & .01 & .08 \\
\hline 2.COOP & 5.69 & .72 & .76 & .40 & .59 & $\mathbf{. 8 0}$ & .06 & .27 & .00 & .07 \\
\hline 3.OC & 4.08 & 1.36 & .89 & .57 & .29 & .25 & $\mathbf{. 8 8}$ & .00 & .03 & .23 \\
\hline 4.RA & 2.14 & 1.04 & .78 & .65 & -.42 & -.52 & -.07 & .77 & .01 & .08 \\
\hline 5.RC & 4.24 & 1.06 & .72 & .47 & .01 & -.07 & -.18 & .10 & .72 & .08 \\
\hline 6.IC & 4.42 & 1.09 & .91 & .50 & .28 & .26 & .48 & -.28 & -.28 & $\mathbf{. 9 2}$ \\
\hline
\end{tabular}

Note: $\mathrm{N}=180$, Cronbach's $\alpha$ in bold on the cross-diagonal, squared correlations above the diagonal, Abbreviations: $\mathrm{SD}=$ Standard deviation, $\mathrm{CR}=$ Composite reliability, $\mathrm{AVE}=$ Average variance extracted, ERCS $=$ Extra-role customer service, $\mathrm{COOP}=$ Cooperative behaviors, $\mathrm{OC}=$ Organizational commitment, $\mathrm{RA}=$ Role ambiguity, $\mathrm{RC}=$ Role conflict, $\mathrm{IC}$ $=$ Internal communication 
Table 2

Hypotheses, Standardized Parameter Estimates and Significance Levels

\begin{tabular}{|c|c|c|c|c|}
\hline & Path & $\begin{array}{c}\text { Std. } \\
\text { estimate }\end{array}$ & $\rho$ & \\
\hline H1a & Organizational commitment $\rightarrow$ ERCS & .32 & $* * *$ & $\mathrm{~S}$ \\
\hline $\mathrm{H} 1 \mathrm{~b}$ & Organizational commitment $\rightarrow$ COOP & .27 & $* * *$ & $\mathrm{~S}$ \\
\hline $\mathrm{H} 2 \mathrm{a}$ & Role ambiguity $\rightarrow$ ERCS & -.48 & $* * *$ & $\mathrm{~S}$ \\
\hline $\mathrm{H} 2 \mathrm{~b}$ & Role ambiguity $\rightarrow$ COOP & -.65 & $* * *$ & $\mathrm{~S}$ \\
\hline $\mathrm{H} 3 \mathrm{a}$ & Role conflict $\rightarrow$ ERCS & .22 & $* * *$ & $\mathrm{R}(+\mathrm{ve})$ \\
\hline $\mathrm{H} 3 \mathrm{~b}$ & Role conflict $\rightarrow$ COOP & .15 & $*$ & $\mathrm{R}(+\mathrm{ve})$ \\
\hline $\mathrm{H} 4 \mathrm{a}$ & Role ambiguity $\rightarrow$ Organizational commitment & & & NS \\
\hline $\mathrm{H} 4 \mathrm{~b}$ & Role conflict $\rightarrow$ Organizational commitment & & & NS \\
\hline $\mathrm{H} 5 \mathrm{a}$ & Internal communication $\rightarrow$ Role ambiguity & -.41 & $* * *$ & $\mathrm{~S}$ \\
\hline $\mathrm{H} 5 \mathrm{~b}$ & Internal communication $\rightarrow$ Role conflict & -.35 & $* * *$ & $\mathrm{~S}$ \\
\hline \multirow[t]{6}{*}{ H6 } & $\begin{array}{l}\text { Internal communication } \rightarrow \text { Organizational } \\
\text { commitment }\end{array}$ & .49 & $* * *$ & $S$ \\
\hline & $\mathrm{R}^{2}-\mathrm{ERCS}$ & .39 & & \\
\hline & $\mathrm{R}^{2}-\mathrm{COOP}$ & .54 & & \\
\hline & $\mathrm{R}^{2}$ - Organizational commitment & .24 & & \\
\hline & $\mathrm{R}^{2}-$ Role ambiguity & .17 & & \\
\hline & $\mathrm{R}^{2}-$ Role conflict & .12 & & \\
\hline
\end{tabular}

Notes: Model fit: CMIN/DF=611.48/395=1.55, CFI=.91, TLI=.90, IFI=.91, RMSEA=.06; $* * * \rho \leq 0.01, * * \rho \leq 0.05, * \rho \leq 0.10$, Abbreviations: NS = Non-significant, $\mathrm{S}=$ Supported, R $=$ Rejected, ERCS $=$ Extra-role customer service behaviors, COOP $=$ Cooperative behaviors, 
Table 3

Mediation Analysis

\begin{tabular}{|c|c|c|c|c|}
\hline & $\begin{array}{c}\text { Direct Effect } \\
\text { (without } \\
\text { mediator) } \\
\text { Std. Reg. } \\
\text { Coefficient } \\
(\rho \text {-value })\end{array}$ & $\begin{array}{c}\text { Direct Effect } \\
\text { (with mediator }) \\
\text { Std. Reg. } \\
\text { Coefficient } \\
(\rho \text {-value })\end{array}$ & $\begin{array}{c}\text { Indirect Effect } \\
\text { Std. Reg. } \\
\text { Coefficient } \\
(\rho \text {-value })\end{array}$ & Mediation \\
\hline IC - RC - ERCS & $.28(\rho<.001)$ & $.03(\rho>.10)$ & $-.07(\rho<.05)$ & $\mathrm{S}^{*}$ \\
\hline IC - RC - COOP & $.35(\rho<.001)$ & $.02(\rho>.10)$ & $-.05(\rho>.10)$ & $\mathrm{NS}$ \\
\hline IC - RA - ERCS & $.28(\rho<.001)$ & $-.05(\rho>.10)$ & $.30(\rho<.01)$ & $\mathrm{S}^{*}$ \\
\hline IC - RA - COOP & $.35(\rho<.001)$ & $-.08(\rho>.10)$ & $.22(\rho<.01)$ & $\mathrm{S}^{*}$ \\
\hline IC - AC - ERCS & $.28(\rho<.001)$ & $-.01(\rho>.10)$ & $.15(\rho<.01)$ & $\mathrm{S}^{*}$ \\
\hline IC - AC - COOP & $.35(\rho<.001)$ & $-.02(\rho>.10)$ & $.17(\rho<.01)$ & $\mathrm{S}^{*}$ \\
\hline
\end{tabular}

Abbreviations: $\mathrm{IC}=$ Internal communication, $\mathrm{RC}=$ Role conflict, $\mathrm{RA}=$ Role ambiguity, $\mathrm{AC}=$ Affective organizational commitment, ERCS $=$ Extra-role customer service behaviors, COOP = Cooperative behaviors, $\mathrm{S}=$ Significant, NS= Non-significant, and * Results support full mediation 
Fig. 1.

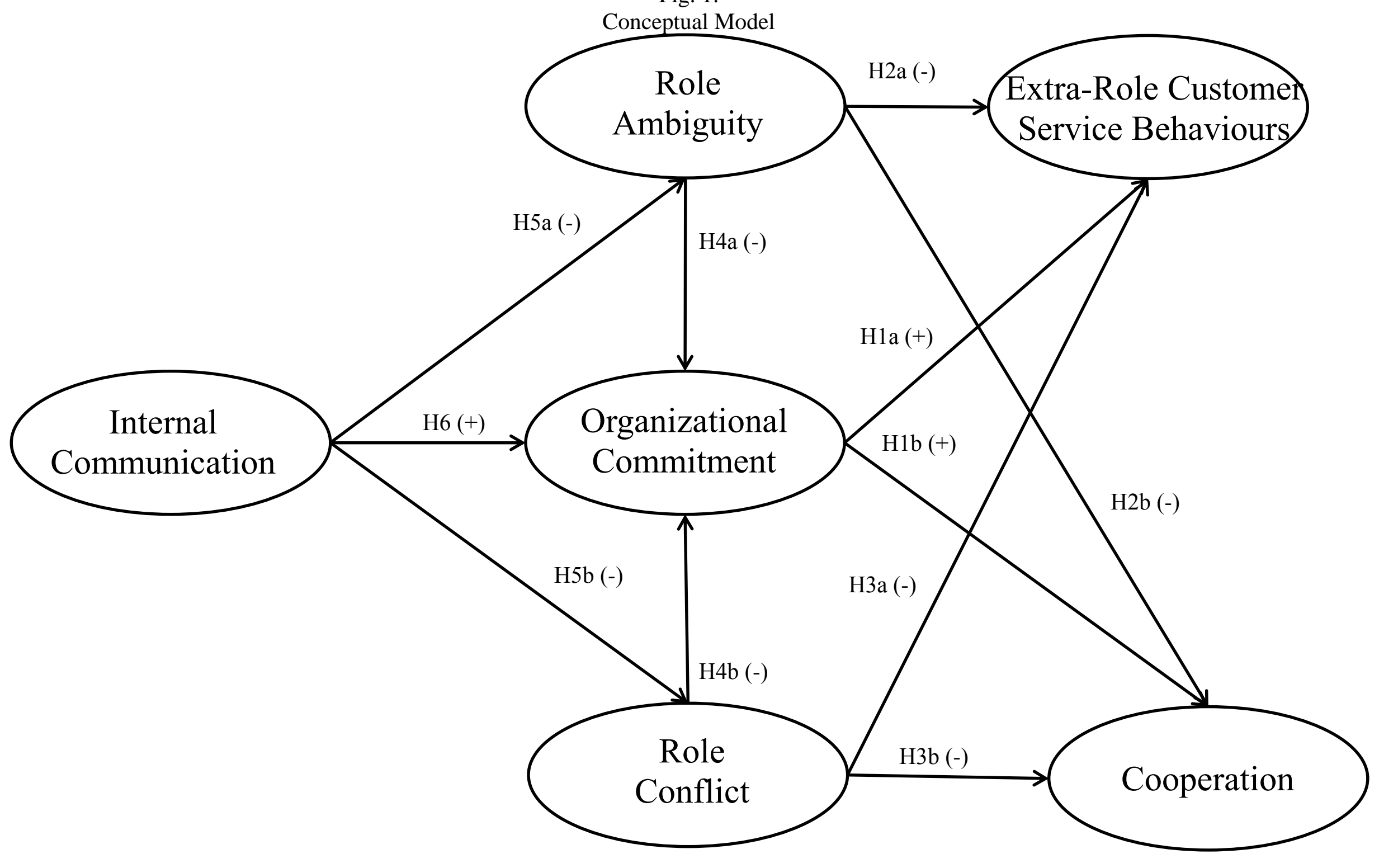

